\title{
URGENSI DIMENSI FAKTOR GEOGRAFIS DALAM PENENTUAN KEBIJAKAN KOMUNIKASI DAN INFORMASI
}

\author{
Oleh: \\ Bambang Syaeful Hadi \\ Jurusan Pendidikan Geografi FISE UNY
}

\begin{abstract}
Abstrak
Perkembangan dalam segala aspek kehidupan manusia mendorong pendekatan multidisipliner dan perkawinan antar cabang ilmu, diantara adalah Geografi Komunikasi sebagai hasil perpaduan Geografi dan IImu Komunikasi. Diantara faktor yang mempengaruhi karakteristik komunikasi, yang dikaji dalam geografi komunikasi adalah aspek-aspek geografis kaitannya dengan karakteristik komunikasi dan tingkah laku keruangan. Faktor geografis merupakan salah satu hal yang perlu dipertimbangkan dalam pembuatan kebijakan karena pembangunan fasilitas komunikasi dan upaya komunikasi bertujuan untuk pencapaian kesejahteraan akan tidak efektif. Faktor tersebut diantaranya: kedekatan dengan pusat-pusat kota, persebaran pusat-pusat kegiatan manusia, jarak dari pusat-pusat pelayanan masyarakat (kesehatan, pendidikan), aksesibilitas wilayah atau rute jalan, mobilitas penduduk, interaksi dengan wilayah lain. Kerangka kebijakan informasi perlu mempertimbangkan tiga trand, yakni : pertama, perkembangan industri informasi yang sangat pesat. Kedua, penggunaan yang lebih luas dimana informasi merupakan sumber bagi pemerintahan, dunia pendidikan maupun lembaga lainnya. Ketiga, penggunaan informasi oleh warga masyarakat untuk meningkat kehidupan atau kesejahteraan.
\end{abstract}

Kata kunci : faktor geografis, kebijakan, komunikasi

\section{Pendahuluan}

Seiring dengan kemajuan ilmu pengetahuan dan teknologi, pengertian dan wawasan manusia terhadap fakta dan gejala lingkungannya menjadi bertambah luas dan mendalam. Kesadaran akan pentingnya aplikasi berbagai disiplin ilmu untuk memecahkan suatu persoalan yang dihadapi manusia mendorong para ahli dari berbgai disiplin ilmu untuk bekerja sama dalam mengimplementsikan ilmunya, sehingga suatu masalah dapat dipecahkan secara komprehensif. Dengan pendekatam multidisipliner, perkembangan berbagai pendekatan dan paradigma keilmuan 
Urgensi Dimensi Faktor Geografis Dalam Penentuan Kebijakan

Komunikasi Dan Informasi

memunculkan berbagai disiplin ilmu baru yang merupakan hasil penelaahan tersendiri maupun hasil perkawinan/perpaduan antara dua atau lebih disiplin ilmu. Salah satu hasil perpaduan konsep keilmuan adalah Geografi Komunikasi, yakni perpaduan antara ilmu Geografi dan IImu Komunikasi, yang berkembang menjadi disiplin ilmu yang berdiri sendiri. Untuk memahami pengertian Geografi Komunikasi, terlebih dahulu harus dipahami pengertian Geografi dan Komunikasi, karena Geografi Komunikasi muncul sebagai disiplin ilmu tersendiri yang merupakan cabang dari Geografi Manusia.

Salah satu definisi Geografi yang cukup populer di Indonesia adalah definisi hasil rumusan Seminar dan Lokakarya Geograf di Semarang tahun 1988 (dalam Suparmini, dkk, 2000) yang menyatakan bahwa Geografi adalah ilmu yang mempelajari persamaan dan perbedaan fenomena geosfir (litosfir, hidrosfir, biosfir, atmosfir, dan antroposfir) dengan sudut pandang/ pendekatan keruangan, kelingkungan, dan kompleks wilayah. Menurut Blij dan Muller (1998) geografi mempelajari lokasi-lokasi dan distrisbusi feature permukaan bumi. Feature yang dimaksud antara lain karakteristik hunian manusia atau sifat-sifat lingkungan alam, tetapi aspek yang paling menarik perhatian geograf adalah interrelasi antara lingkungan alam dengan masyarakat manusia. Pendekatan terhadap aspek manusia dan dunia alam dipandu oleh perspektif keruangan (spatial perspektive) Sementara menurut Effendi (2000,) komunikasi hakekatnya adalah proses pernyataan antar manusia, yang dinyatakan adalah pikiran atau perasaan seseorang kepada orang lain dengan menggunakan bahasa sebagai alat penyalurnya. Dalam bahasa komunikasi, pernyataan dinamakan pesan (message), orang yang menyampaikan pesan disebut komunikator, sedangkan orang yang menerima pesan disebut komunikan (communicatee). Secara tegas dapat dinyatakan bahwa komunikasi adalah proses penyampaian pesan oleh komunikator kepada komunikan. Pesan komunikasi terdiri dari dua aspek, yakni isi pesan (the content of the message) dan lambang (symbol). Konkritnya, isi pesan adalah pikiran atau perasaan, lambang adalah bahasa.

Berdasarkan pengertian dan arti istilah-istilah dalam geografi dan ilmu komunikasi, dapat ditarik suatu kaitan antara istilah-istilah tersebut untuk mencoba mendefinisikan terminologi Geografi Komunikasi. Hanya perlu diingat bahwa tidak semua wilayah kajian IImu Komunikasi dipelajari dalam Geografi Komunikasi, mengingat bahwa yang dipentingkan dalam geografi komunikasi adalah ruang tempat terjadinya komunikasi (analsisis lokasional), aliran atau transmisi informasi atau pesan, kuantitas dan kualitas aliran informasi antar ruang, distribusi fasilitas media komunikasi dan efek media masa terhadap tingkah laku keruangan manusia dan lingkungan (Albar dalam Hurst, 1986). Fenomena komunikasi merupakan 
fenomena sosial (antroposfir), oleh karena itu bidang kajian komunikasi dipelajari dalam Geografi Manusia/Sosial. Dengan demikian dapat dinyatakan disini bahwa geografi komunikasi adalah cabang dari geografi sosial yang mempelajari gejala aliran atau pergerakan massa psikal (tidak berbentuk benda) yang berupa ide/gagasan, informasi, dan atau data dan sejenisnya dari satu tempat ke tempat lain dengan menggunakan media tertentu dengan pendekatan keruangan, kelingkungan (ekologi), dan kompleks wilayah.

Para ahli geografi tertarik untuk memasukkan fenomena komunikasi sebagai objek kajiannya, karena ternyata aktivitas komunikasi berdampak pada ruang sosial manusia, aktivitas/tingkah laku keruangan, diffusi keruangan, dan menjadi pertimbangan manusia dalam menentukan keputusan pilihan lokasi untuk melakukan kegiatan hidupnya, seperti menentukan lokasi permukiman, keputusan untuk melakukan migrasi, penentuan lokasi pusat kegiatan perekonomian, adaptasi dan pembentukan persepsi lingkungan. Informasi yang diterima seseorang terhadap suatu lokasi akan memunculkan tanggapan yang beragam dan membawa pengaruh terhadap aktivitas keruangan yang dilakukannya. Hanya biasanya terdapat kecenderungan umum di dalam merespon informasi tentang lingkungan di sekitarnya.

\section{Faktor-faktor Geografis yang Terkait Komunikasi dan Informasi}

Karakteristik komunikasi antar suatu daerah dengan daerah lainnya mungkin akan berbeda-beda. Adanya perbedaan tersebut dapat disebabkan karena agihan fasilitas pendukung komunikasi, budaya, ataupun kondisi geografis sangat menentukan jenis kebijakan apa yang harus dilakukan terhadap suatu daerah. Diantara sekian banyak faktor yang mempengaruhi karakteristik komunikasi, yang dibahas dalam geografi komunikasi tentu saja aspek-aspek geografis kaitannya dengan karakteristik komunikasi dan tingkah laku keruangan.

Faktor-faktor geografis yang menentukan karakteristik komunikasi di daerah tertentu :

1. Kedekatan dengan pusat-pusat kota

Pusat kota merupkan bagian dari kota yang mempunyai aktivitas yang paling tinggi, oleh karena itu ia juga sekaligus menjadi pusat informasi yang dapat disebarkan segala penjuru daerah sebagai daerah pengaruh.

2. Persebaran pusat-pusat kegiatan manusia

Pusat-pusat kegiatan manusia diantaranya adalah pusat perdagangan, pusat pemerintahan, pusat rekreasi, dan lain-lain. Pusatpusat kegiatan ini menjadi tempat bertemunya antara individu dengan 
Urgensi Dimensi Faktor Geografis Dalam Penentuan Kebijakan

Komunikasi Dan Informasi

individu, individu dengan kelompok atau kelompok dengan kelompok. Dalam pertemuan tersebut masig-masing membawa pesan. Kedatangan mereka ke tempat tersebut juga berdasarkan atas sejumlah informasi yang mereka terima. Informasi tersebut mendorong mereka untuk mendatang tempat-tempat tersebut. Sehingga daerah-daerah yang dekat dengan ousat-pusat kegiatan manusia akan lebih cepat dalam melakukan perubahan-perubahan sosial dan kesejahteraannya.

3. Jarak dari pusat-pusat pelayanan sosial (kesehatan, pendidikan).

Sebagaimana pusat-pusat kegiatan manusia, pusat-pusat pelayanan sosial juga merupakan arena bertemunya manusiameski dengan motivasi yang berbeda, tetap saja pusat-pusat pelayanan sosial menjadi tempat kominikasi yang intensif. Bahkan lembaga pendidikan merupakan arena komunikasi yang memiliki kuantitas dan kualitas informasi terbaik diantara tempat-tempat komunikasi lainnya. Lembaga pendidikan ini disamping sebagai arena komunikasi antar civitas akademika lembaga, juga sebagai sumber informasi penting yang dapat menentukan maju mundurnya sebuah bangsa. Oleh karena itu daerahdaerah yang banyak memiliki lembaga-lembaga pendidikan (apalagi pendidikan tinggi) memiliki keumdahan dalam akses informasi, sehingga mudah dalam menerima inovasi.

4. Aksesibilitas wilayah atau rute jalan

Suatu wilayah yang mudah dijangkau (karena tersedia jaringan jalan yang mencukupi) dimana arus lalu lintas yang menghubungkan antar tempat dapt melalui daerah tersebut, maka daerah tersebut akan lebih cepat dalam menerima informasi. Mengapa demikian ? Hal ini terjadi karena biasanya bersamaan dengan transportasi material mengalir pula sejumlah informasi. Berdasarkan kenyataan ini dapat dimengerti bila daerah yang memiliki tingkat aksesibilitas tinggi akan lebih cepat maju daripada daerah yang tingkat aksesibilitasnya rendah.

Sementara masing-masing media komunikasi juga memiliki tingkat aksesibilitasnya sendiri-sendiri. Di dalam suatu jaringan telekomunikasi, ukuran dari kapasitas optimum jalan raya informasi adalah lebar gelombangnya (bandwidth), yang bisa diukur dengan bit per second (bps) atau syclus per second (hertz). Bagi komputer yang menghubungkan jaringan melalui modem dan jaringan kabel standard, bandwidth maksimum yang tersedia besarnya beragam antara 2400 sampai 28.800 bps (saluran gelombang sempit (narrowband), saluran ini dipakai untuk komunikasi dan transmisi rutin yang datanya relatrif sedikit, seperti facsimili atau file-file komputer biasa. Sementara untuk komunikasi dan transmisi yang datanya lebih besar dapat menggunakan broadband atau "jalan raya super" untuk saluran informasi 
superhighway, yang memakai kabel-kabel serat optik (coaxial), yang dapat menyalurkan jutaan bit per detiknya, misalnya televisi, videotex, file-feile komputer yang mengandung video dan audio, atau game yang biasa digunakan oleh jaringan internet serta layanan-layanan interaktif, seperti pesan belanja dari rumah atau pesan video (Fidler, 2003).

5. Mobilitas penduduk

Perpindahan penduduk dari satu tempat ke tempat lain, tentu tidak hanya pindah secara fisik tetapi ia juga membwa sejumlah informasi yang dapat dikomunikasikan. Perpindahan penduduk dari suatu tempat ke tempat lain sesungguhnya dilakukan berdasarkan informasi yang di peroleh mengenai daerah lain. Adanya daya tarik tempat yang didengar oleh para pelaku mobilitas mendorong orang untuk mendatangi tempat tersebut. Setelah mereka mendatangi suatu daerah, maka dia akan mengirim sejumlah pesan kepada orang-orang seasal daerahnya mengenai tempat yang kini ia huni.

6. Interaksi dengan wilayah lain

Suatu daerah yang terisolasi akan memiliki karakteristik komunikasi yang berbeda dengan daerah yang terbuka, terbuka dalam pengertian memiliki tingkat interaksi yang tinggi dengan daerah lain di sekitarnya. Di daerah yang terbuka, jenis-jenis komunikasi lebih kompleks (baik yang murni aliran pesan maupun yang mendompleng pada aliran material), volume arus pesan lebih tinggi.

Keenam faktor yang berkaitan dengan aspek geografis tersebut mempengaruhi intensitas, kualitas, dan kuantitas informasi yang diterima oleh penduduk. Sebagai faktor sosio-geografis, faktor-faktor tersebut kondisinya antar daerah mungkin berbeda, oleh karena itu untuk mengetahui korelasi faktor tersebut dengan karakteristgik komunikasi dapat dilakukan penelitian yang seksama.

\section{Revolusi Cybernetika}

Munculnya berbagai alat komunikasi telah mengubah tata perilaku komunikasi, perubahan pengorganisasian ruang, dan munculnya realitas sosial yang baru sebagai pengaruh dari realitas yang ditampilkan media. Media telah memiliki hegemoni yang kuat dalam ruang pikiran dan ruang sosial manusia. Bahkan media komunikasi telah memiliki realitas tersendiri yang disebut sebagai realitas virtual, disamping reaalitas sosial yang ada sebagai realitas aktual. Sejak berkembangnya telpon dan radio, sebtulnya manusia telah mulai memasuki realitas virtual, dimana manusia yang berada pada jarak yang jauh seolah dapat berada satu ruangan secara fisik. Perkembangan radio dan televisi telah membantu membangun realitas virtual, dimana alam atau kondisi yang sama sekali asing dengan membawa 
Urgensi Dimensi Faktor Geografis Dalam Penentuan Kebijakan

Komunikasi Dan Informasi

pengalaman aural dan viasual dapat memasuki ruang-ruang rumah penduduk. Hanya saja dunia penyiaran tidak memiliki ciri-ciri interpersonal yang diperlukan untuk menciptakan suatu dunia virtual partisipatori. Baru sejak kemunculan jaringan CMC (computer-mediated communication) atau komunikasi bermedia komputer.

Media komunikasi CMC berkembang sangat pesat, apalagi dengan digunakannya teknologi komunikasi gelombang cahaya, star trek, cyber, laser, kabel-kabel serat optik, kawat dari kaca. Perkembangan media komunikasi yang sangat mengejutkan karena banyak diantara media yang penggunaannya melebihi dari apa yang dirancang oleh pembuatnya. Pada abad-abad mendatang kemungkinan akan muncul media komunikasi yang mengejutkan. Pada abad 21 sekarang ini yang disebut sebagai millennium ketiga, sehingga John Naisbit menyebutnya sebagai gelombang ketiga merupakan era cybernetika. Lewat teknologi cybernetika ini, orang dari berbagai belahan dunia dapat saling berkomunikasi dan hidup dalam alam maya. Batas-batas geografis region tidak menjadi penghalang bagi orang untuk berinteraksi, sehingga pada masa mendatang batas-batas region dalam kaitannya dengan interaksi keruangan sebagaimana yang dikemukakan oleh para ahli geografi intuitif-kualitatif perlu dirombak bila tidak ingin ditinggalkan. Sekarang yang diperlukan dalam analisis interaksi keruangan adalah pola aliran informasi, setelah itu baru barang dan manusianya. Karena manusia boleh saja tidak pergi kemana-mana secara fisik, tetapi mungkin ia sebenarnya mempunyai mobilitas yang tinggi di dalam alam virtual. Sehingga hasil selancarnya (surfing) di dunia maya dapat melebihi hasil kerja orang yang melakukan mobilitas terestrial. Inilah pekerjaan yang menjanjuikan di masa depan.

\section{Kebijakan Informasi}

Menurut Robert D. Stuart dalam Konfrensi Internasional Manajemen Informasi Digital dalam Era Informasi pada tanggal 28-30 Agustus 2003 di Yogyakarta bahwa kerangka kebijakan informasi perlu mempertimbangkan tiga trend, yakni : pertama, perkembangan industri informasi yang sangat pesat. Kedua, penggunaan yang lebih luas dimana informasi merupakan sumber bagi pemerintahan, dunia pendidikan maupun lembaga lainnya. Ketiga, penggunaan informasi oleh warga masyarakat untuk meningkat kehidupan atau kesejahteraan (KR, 30/8/03). Faktor ketiga inilah yang sesungguhnya sangat penting karena yang terpenting bagi manusia adalah tingkat kesejahteraannya. Kehidupan politik, peningkatan pendidikan, industrialisasi muara akhirnya adalah meningkatkan kesejahteraan.

Perkembangan media komunikasi dan semakin kompleksnya tingkah laku keruangan manusia, tentu perlu disikapi secara arif oleh pemerintah. 
Aturan baik yang bersifat larangan atau anjuran saat ini tidak bisa begitu saja dikeluarkan, karena berbagai keterbatasan dan pesatnya laju kecanggihan teknologi yang sulit dikejar dengan teknologi pengendali. Akses internet, baik yang berupa image, video, teletex, videotex dapat dilakukan orang kapan saja dimana saja. Isi dari pesan-pesan tersebut sangat sulit dikontrol. Sebagai contoh larangan menyaksikan adegan pornografi akan sulit dilakukan, karena pesan pornografi sangat banyak terdapat pada alam virtual. Oleh karenya yang paling penting bukan larangannya secara langsung, tetapi melalui pembangunan akhlak manusianya yang memungkinkan manusia untuk tidak mengakses pesan-pesan demikian. Bila segala infoermasi yang buruk secara noramtif dapat diakses dari dunia maya, maka akan sangat sulit mengontrolnya. Oleh karena itu, pendidikan sebagai benteng pertahanan harus lebih diberdayakan sebagai upaya untuk mempertahankan jati diri dan nilai-nilai keagamaan dana keindonesiaan (nasionalisme) yang kita miliki. Sekarang ini, melalui dunia maya dunai sangat terbuka. Segala jenis informasi dapat diperoleh dari media CMC. Oleh karena itu, di era keterbukaan ini para pembuat kebijakan perlu transparan dalam membuat kebijakan.

\section{DAFTAR PUSTAKA}

Abler, R.F. The Geography of Communication in Michael. Eliot Hurst, 1974. Transportation Geography (Comments and Readings). New York : McGraw-Hill Book Company.

Bintarto, R., 1988. Metode Analisa Geografi. Jakarta : Penerbit LP3ES.

Blij, H.J. de \& Peter O. Muller, 1999. Geography : Realms, Regions, and Concepts. Eigdt Edition. New York : John Wiley \& Sons Inc.

Bungin, Burhan, 2001. Imaji Media Massa (Konstruksi dan Makna Realitas Sosial Iklan Televisi dalam Masyarakat Kapitalistik). Yogyakarta : Penerbit Jendela

Daljuni, 1992. Geografi Baru : Organisasi Keruangan dalam Teori dan Praktek, Bandung: Penerbit Alumni

Effendy, Onong Uchjana, 2000. IImu, Teori, dan Filsafat Komunikasi. Bandung : Penerbit PT.Citra Aditya Bakti.

Felmann, Jerome, Arthur Getis and Judith Getis, 1997. Human Geography Landscapes of Human Activities. Fifth Edition. Madison : Brown \& Benchmark Publisher. 
Urgensi Dimensi Faktor Geografis Dalam Penentuan Kebijakan

Komunikasi Dan Informasi

Fidler, Roger, 2003. Mediamorfosis Memahami Media Baru. Yogyakarta : Penerbit Bentang. Terjemahan Hartono hadikusumo. Edisi asli berjudul Metamorphosis Understanding New Media

Koentjoroningrat, 1989. Pengantar Ilmu Antropologi. Cet. Kedelapan. Jakarta : Penerbit Aksara Baru.

Soekanto, Soerjono. 1990. Sosiologi Suatu Pengantar. Cet. Ke-18. Jakarta: PT Rajawali Press.

Sumaatmadja, Nursid, 1988. Studi Geografi (Suatu Pendekatan dan Analisa Keruangan). Bandung : Penerbit Alumni

Suparmini, dkk, 2000. Dasar-dasar Ilmu Geografi. Edisi Revisi 1. Yogyakarta : Penerbit Jurdik Geografi. 